\title{
The Acute Metabolic Effects of Glucagon and Its Interactions with Insulin in Forearm Tissue
}

\author{
S. H. Schneider, S. E. Fineberg, and G. L. Blackburn \\ Department of Medicine, Boston University School of Medicine, Boston, Massachusetts, \\ and Department of Medicine Indiana University School of Medicine, Indianapolis, Indiana, USA
}

\begin{abstract}
Summary. The acute effects of glucagon (mol. wt. 3500 ) and its interactions with insulin were studied in the forearm during eight studies in seven normal, post-absorptive males. The protocol consisted of a $2 \mathrm{~h}$ baseline, $1 \mathrm{~h}$ glucagon perfusion (mean glucagon increment, $691 \pm 50 \mathrm{pg} / \mathrm{ml}), 1 \mathrm{~h}$ perfusion of both insulin and glucagon (mean insulin increment of 105 $\pm 13 \mathrm{mU} / \mathrm{l}$ ) and a $30 \mathrm{~min}$ recovery period. Simultaneous arterial (A), deep venous (DV), and superficial venous (SV) blood samples were obtained at $30 \mathrm{~min}$ intervals. Perfusion of glucagon resulted in a decrease in (A-DV) non-esterified fatty acids of $-0.128 \pm 0.057 \mathrm{mmol} / \mathrm{l}(\mathrm{n}=7, \mathrm{p}<0.05)$ and (A-SV) non-esterified fatty acids of $-0.081 \pm$ $0.036 \mathrm{mmol} / 1(\mathrm{n}=7, \mathrm{p}<0.05)$, as well as a change in deep compartment uptake of glycerol after $60 \mathrm{~min}$ of $-0.044 \pm 0.019 \mu \mathrm{mol} / \mathrm{min} / 100 \mathrm{ml}$ of forearm tissue $(\mathrm{n}=6, \mathrm{p}<0.05)$, indicating increased lipolysis. There was also a decrease in net glucose uptake as reflected by a change in (A-DV) of $-0.24 \pm 0.09$ $\mathrm{mmol} / \mathrm{l}(\mathrm{n}=7, \mathrm{p}<0.025)$ and $(\mathrm{A}-\mathrm{SV})$ of $0.10 \pm$ $0.05 \mathrm{mmol} / \mathrm{l}(\mathrm{n}=7, \mathrm{p}<0.05)$. There was also a net decrease in deep arteriovenous differences of potassium in six of seven subjects. Insulin levels, similar to those found after a meal, rapidly reversed the effects of glucagon on non-esterified fatty acid, glucose and potassium. These effects persisted throughout the recovery period.
\end{abstract}

Key words: Forearm perfusion, serum insulin, plasma glucagon, glucose, plasma non-esterified fatty acids, blood ketone bodies, blood glycerol, glucagon, extrahepatic effects.

Glucagon levels are reported to be elevated in a number of pathological states in man, including renal and [1] hepatic disease [2], stress [3], sepsis [4] and diabetic ketoacidosis $[5,6]$. These elevations may be due in part to non-bioactive glucagon [7]. The contribution of bioactive glucagon (mol. wt. 3500) to the metabolic abnormalities of such states remains a matter of conjecture.

Significant hepatic effects of glucagon have been observed in all species. These include stimulation of glycogenolysis, gluconeogenesis, and ketogenesis [8]. In non-primates physiological concentrations of glucagon enhance lipolysis in vitro. However, such studies must be applied to man with caution because of marked interspecies differences $[9,10,11]$. Systemic administration of supraphysiological doses of glucagon leads to insulin and adrenaline release [12], thus clouding the interpretation of such experiments. Recent investigations during which somatostatin was infused suggest that abnormalities in glucagon secretion may worsen metabolic control in insulin deficient diabetes mellitus $[13,14]$.

The intent of these experiments was to examine the local effects of glucagon both in the absence and presence of increments in insulin. Using the forearm perfusion technique glucagon increments could be achieved without perturbing systemic metabolism. Glucagon concentrations were increased in the forearm venous circulation to levels similar to those occurring in ketoacidosis [5,6], and insulin to venous levels similar to those seen after a meal in normal individuals.

\section{Materials and Methods}

\section{Subject Selection}

Seven healthy, non-obese (within $100 \pm 15 \%$ of ideal body weight as defined by Metropolitan Life Insurance Tables, 1959) male volunteers were used in eight studies. Subjects took no medication of any kind, had no family history of diabetes, and regularly ingested at least $160 \mathrm{~g}$ of carbohydrate and $1 \mathrm{~g}$ of protein $\mathrm{kg}^{-1}$ 
$\mathrm{day}^{-1}$. Informed consent was obtained prior to each experiment. All procedures were performed in the Thorndike Clinical Research Center of Boston University Medical Center at Boston City Hospital. Perfusions were begun at $0900 \mathrm{~h}$, after an overnight fast of $12-14 \mathrm{~h}$, and continued until approximately $1330 \mathrm{~h}$. The experiments were performed in accordance with the principles of the Declaration of Helsinki.

\section{Forearm Technique}

These studies used a minor modification of the forearm perfusion technique of Andres and Zierler previously described [15, 16]. Deep venous and superficial venous catheters were inserted in a retrograde manner. The brachial artery was cannulated with an $18 \mathrm{~g}$, thin wall Cournand needle. A double-lumen Lilienthal adaptor fitted to the arterial needle allowed sampling of incoming arterial blood via a central stainless steel cannula and perfusion of the forearm distal to the arterial sampling site. The circulation of the arm was perfused at $0.10 \mathrm{ml} / \mathrm{min}$. Five minutes prior to and throughout each sampling period the hand circulation was occluded at the wrist by a paediatric blood pressure cuff to prevent mixing between venous beds [17]. Simultaneous arterial and venous specimens were obtained. Evans Blue $(150 \mu \mathrm{g} / \mathrm{min})$ was perfused throughout the experiment to monitor blood flow as calculated by a modified Fick principle [16].

\section{Experimental Protocol}

The protocol used consisted of a $2 \mathrm{~h}$ baseline period, $1 \mathrm{~h}$ of glucagon perfusion alone, $1 \mathrm{~h}$ of glucagon and insulin, and a $30 \mathrm{~min}$ recovery period. Samples were obtained at $30 \mathrm{~min}$ intervals throughout. The baseline and recovery perfusates consisted of $0.125 \mathrm{~g}$ human serum albumin and $75 \mathrm{mg}$ Evans Blue in $50 \mathrm{ml}$ of $0.154 \mathrm{~mol} / \mathrm{l}$ saline. Glucagon and glucagon-insulin perfusates contained saline, human serum albumin, Evans Blue and the designated hormone(s). The glucagon perfusion was calculated to give a forearm venous plasma increment of $400 \mathrm{pg} / \mathrm{ml}$ based on a mean forearm plasma flow of $30 \mathrm{ml} / \mathrm{min}$. Glucagon (lyophilised; USP, Eli Lilly, lot number 9PB59A) was used. For the insulin-glucagon period single component pork insulin (Eli Lilly lot number XX0240AMX/-C2Ct3016-4A) was added to a $25 \mathrm{ml}$ aliquot of the glucagon perfusate. The dose of insulin was calculated to give an average venous plasma increment of $100 \mathrm{mU} / 1$. Four sets of samples, arterial (A), deep venous (DV), and superficial venous (SV) were obtained during the baseline period. Two sets were obtained during the glucagon perfusion, two during glucagon plus insulin and one during the recovery period. Glucagon and insulin were gifts of Dr. John Galloway of Eli Lilly Laboratories.

\section{Sample Handling}

Blood samples of $14 \mathrm{ml}$ were obtained from each sampling site simultaneously. Four $\mathrm{ml}$ of whole blood was quickly mixed with $4 \mathrm{mI}$ of chilled $30 \%(\mathrm{v} / \mathrm{v})$ perchlorate and kept at $-20^{\circ} \mathrm{C}$ until later analysis for lactate, pyruvate, glycerol, 3-hydroxybutyrate, and acetoacetate. Frozen filtrates (kept at $-20^{\circ} \mathrm{C}$ until needed) for substrate measurements were neutralized on the day of analysis (within 30-60 days of sampling). The maximum loss of substrate during such storage was $20 \%$ and all samples from a given study were analyzed in the same assay. Two $\mathrm{ml}$ of whole blood was placed in a tube containing 1000 International Units of Trasylol (FBA Pharmaceuticals), spun at $4^{\circ} \mathrm{C}$ and the plasma removed and frozen for later glucagon determination. One $\mathrm{ml}$ was placed in a disposable Wintrobe tube for measurement of plasmacrit (1haematocrit). The remainder of the sample was spun twice at $4^{\circ} \mathrm{C}$.
This plasma was used for determination of dye, non-esterified fatty acids (NEFA), glucose and potassium concentrations. Concentrations were corrected for heparin-filled syringe dead space.

\section{Analytical Methods}

NEFA, glucose, glycerol, lactate, pyruvate, ketone bodies and hormone levels were determined in duplicate. Potassium concentrations were assessed in triplicate. Glucose was analysed by a glucose oxidase, colorimetric method, and glycerol, 2-hydroxybutyrate, acetoacetate, pyruvate and lactate were analysed by enzymatic techniques [18]. The coefficients of variation (CV) for these methods are $0.7,4.8,6.2,3.4,1.1$, and $1.2 \%$ respectively. Potassium concentrations were measured by internal standard flame photometry. NEFA concentrations were measured by a modification of the method of Novak, CV 7\% [19]. Plasma insulin concentrations were determined by radioimmunoassay using Wright antibody lot number 496 and a charcoal separation technique previously described [15]. Plasma glucagon concentrations were determined by radioimmunoassay using $30 \mathrm{~K}$ antibody, lot number 33 , pool number 2 supplied by Dr. Roger Unger of Texas Southwest Medical School. Insulin and glucagon standards were a gift of Dr. Mary Root of Eli Lilly Laboratories.

\section{Data Handling}

Arteriovenous differences across the deep vein (A-DV) and superficial vein (A-SV) reflect ongoing metabolism in the two forearm compartments. Previous conventions concerning data handling during unstable flow periods were observed [15]. Uptake or output estimates (plasma flow or whole blood flow $\mathbf{x}$ arteriovenous difference $=Q^{*}$ ) were obtained for the deep compartment tissues but could not be estimated accurately for the superficial tissues of the forearm because of individual variability of flow across this compartment [20].

Repeated measurements within a particular observation period were pooled for each experiment and group means were obtained. A positive arteriovenous difference or $\mathrm{Q}^{\circ}$ reflects net uptake or decreased output of a particular constituent across a venous bed. A negative difference or $Q^{\prime}$ reflects either output or decreased uptake across that compartment. Prior to interperiod analysis, data were compared using repeated measure analysis of variance. Interperiod differences were examined only when the analysis of variance was significant $(\mathrm{p}<0.05)$. Within period means were evaluated to determine if a mean was significantly positive or negative using one tailed Student $t$ tests. The hypotheses posed were that glucagon would have effects opposite to that of insulin (one tailed questions). Inter-period means were compared by paired analysis. Data are presented as mean \pm SEM or mean \pm the standard error of the difference (SED) [21]. Data were analysed from seven subjects by pooling two sets of experimental results and from the single individual who was studied twice. All data analysis was performed for the seven individuals except for hormone concentrations.

\section{Results}

\section{Plasma Flow}

Plasma flow was stable in all but one subject with an increase of less than $20 \%$ between the baseline and experimental periods for all subjects. In subject 7 there was an increase in flow during sampling period 3 . The flow then plateaued at a new level. 
Table 1. Mean baseline period arteriovenous differences of plasma constituents

\begin{tabular}{|c|c|c|c|c|c|}
\hline Constituent & $(A-D V) \pm S E M$ & $\mathrm{P}$ & $(A-S V) \pm S E M$ & $\mathrm{P}$ & $\begin{array}{l}\text { Deep versus } \\
\text { superficial }\end{array}$ \\
\hline Glucose & $+0.46 \pm 0.07$ & $<0.01$ & $+0.48 \pm 0.05$ & $<0.01$ & NS \\
\hline Potassium & $+0.09 \pm 0.05$ & NS & $+0.17 \pm 0.03$ & $<0.01$ & NS \\
\hline Lactate & $-0.098 \pm 0.058$ & NS & $-0.214 \pm 0.041$ & $<0.01$ & NS \\
\hline NEFA & $+0.082 \pm 0.048$ & NS & $-0.081 \pm 0.050$ & NS & $<0.05$ \\
\hline Glycerol & $-0.007 \pm 0.008(6)$ & NS & $-0.028 \pm 0.015(6)$ & NS & $<0.05$ \\
\hline Acetoacetate & $+0.056 \pm 0.023$ & $<0.05$ & $+0.041 \pm 0.018$ & $<0.05$ & $<0.05$ \\
\hline 3-hydroxybutyrate & $+0.097 \pm 0.026$ & $<0.01$ & $+0.122 \pm 0.038$ & $<0.025$ & NS \\
\hline Pyruvate & $0.000 \pm 0.006$ & NS & $-0.015 \pm 0.004$ & $<0.01$ & $<0.025$ \\
\hline
\end{tabular}

Results are shown in mmol/l. $\mathrm{A}=$ arterial, $\mathrm{DV}=$ deep venous and $\mathrm{SV}=$ superficial venous. The numbers in parentheses indicate the number of subjects analysed. In general, four observations contributed to an individual mean during the baseline period for each experiment. $\mathbf{P}=$ the probability that a particular mean is significantly negative or positive is given. Significance was assessed by a single tail $t$ test. The last column is the probability that paired mean deep and superficial arteriovenous differences are negative or positive (single tail t test)

Table 2. Effects of glucagon and glucagon + insulin perfusion on metabolite uptake across the deep venous bed in $\mu \mathrm{mol} / \mathrm{min} / 100 \mathrm{ml}$ of forearm tissue

\begin{tabular}{|c|c|c|c|c|}
\hline \multicolumn{5}{|l|}{ Period } \\
\hline Period & Baseline $^{a}$ & Glucagon $^{\mathrm{b}}$ & Glucagon + insulin $^{c}$ & Recovery ${ }^{\mathrm{d}}$ \\
\hline Glucose & $+0.90 \pm 0.15$ & $+0.64 \pm 0.14$ & $+2.16 \pm 0.40$ & $+2.29 \pm 0.39$ \\
\hline Potassium & $+0.18 \pm 0.08$ & $-0.02 \pm 0.12$ & $+0.63 \pm 0.14$ & $+0.72 \pm 0.18$ \\
\hline NEFA & $+0.143 \pm 0.076(7)$ & $-0.053 \pm 0.102$ & $+0.315 \pm 0.077$ & $+0.590 \pm 0.155$ \\
\hline Glycerol & $+0.000 \pm 0.025$ & $-0.064 \pm 0.043(6)$ & $+0.011 \pm 0.109$ & $+0.091 \pm 0.053$ \\
\hline Lactate & $-0.394 \pm 0.298(6)$ & $-0.604 \pm 0.184(6)$ & $-0.795 \pm 0.200(6)$ & $-0.453 \pm 0.286(6)$ \\
\hline Pyruvate & $+0.003 \pm 0.004(6)$ & $+0.034 \pm 0.038(6)$ & $+0.079 \pm 0.076(6)$ & $-0.002 \pm 0.028$ \\
\hline Acetoacetate & $+0.177 \pm 0.053(6)$ & $+0.153 \pm 0.049$ & $+0.250 \pm 0.040$ & $+0.168 \pm 0.084(6)$ \\
\hline 3-hydroxybutyrate & $+0.264 \pm 0.056(6)$ & $+0.242 \pm 0.141$ & $+0.297 \pm 0.054(6)$ & $+0.794 \pm 0.224$ \\
\hline
\end{tabular}

The numbers in parentheses refer to the number of subjects analysed. The mean of experimental means is given. In general, there were four observations each for baseline, two for glucagon and glucagon plus insulin and one for recovery period

a Significant within period uptake or output: glucose, $\mathrm{p}<0.01$; potassium $<0.05$; acetoacetate $<0.01$; 3-hydroxybutyrate $<0.01$

b Significant within period uptake or output: glucose, $\mathrm{p}<0.01$; lactate $<0.01$; acetoacetate $<0.025$. The following differed from the baseline period: glucose $<0.05$ and NEFA $<0.05$

c Significant within period uptake or output: glucose, $\mathrm{p}<0.01$; potassium $<0.01$; lactate $<0.01$; NEFA $<0.01$; acetoacetate $<0.01$; 3-hydroxybutyrate $<0.01$. The following were greater or less than the baseline period: glucose $<0.025$; potassium $<0.05$; and lactate $<0.05$. The following were significantly different from the glucagon period: glucose $<0.01$; potassium $<0.01$; and NEFA $<0.01$

${ }^{d}$ Significant within period uptake or output: glucose, $\mathrm{p}<0.01$; potassium $<0.01$; NEFA $<0.01$; acetoacetate $<0.05$; 3-hydroxybutyrate $<0.01$. The following were different from the baseline period: glucose $<0.01$; potassium $<0.05 ; \mathrm{NEFA}<0.01$; glycerol $<0.05$ and 3-hydroxybutyrate $<0.05$

\section{Arterial Concentrations of Metabolites and Potassium}

Concentrations of potassium and all metabolites except for acetoacetate were stable throughout. Acetoacetate concentrations rose slightly during the study but were significantly elevated above control at only one observation point (the first sample of the glucagon plus insulin period, $\mathrm{p}<0.05$ )

\section{Baseline Characteristics of the Deep and Superficial Beds}

Arteriovenous differences of various plasma constituents measured across forearm tissues in the baseline period are shown in Table 1. Deep arteriovenous differences reflected a net uptake of glucose, acetoacetate, and 3-hydroxybutyrate.

Uptake or output across the deep tissues ( $\left.Q^{\cdot} \mathrm{DV}\right)$ is shown in Table 2 and was qualitatively similar to that of arteriovenous differences alone.

Arteriovenous differences across superficial tissues (Table 1) indicated a significant net fractional output of lactate and pyruvate. Five of seven subjects had negative (A-SV) NEFA during the baseline period (Table 4). The ratio of NEFA to glycerol was highly variable from individual to individual, ranging from 2.8 to 8.1 . Net uptake of glucose, potassium, acetoacetate and 3-hydroxybutyrate were also indicated. 
Table 3. Plasma hormone concentrations

\begin{tabular}{lccc}
\hline Perfusion period & A & DV-A & SV-A \\
\hline Insulin $(\mu \mathrm{U} / \mathrm{ml})$ & & & \\
Basal & $7.3 \pm 1.8$ & $-0.7 \pm 0.6$ & $-0.4 \pm 0.6$ \\
Glucagon & $8.2 \pm 2.1$ & $-0.3 \pm 0.9$ & $-1.1 \pm 0.8$ \\
Glucagon and & & & \\
insulin & $13.1 \pm 3.7$ & $106.0 \pm 26.8$ & $103.4 \pm 26.2$ \\
Recovery & $8.3 \pm 1.4$ & $3.4 \pm 1.7$ & $2.5 \pm 1.9$ \\
Glucagon $(\mathrm{pg} / \mathrm{ml})$ & & & \\
Basal & $117 \pm 22$ & $-9 \pm 7$ & $-12 \pm 11$ \\
Glucagon & $167 \pm 23$ & $688 \pm 50$ & $700 \pm 64$ \\
Glucagon and & & & \\
insulin & $224 \pm 62$ & $713 \pm 90$ & $718 \pm 92$ \\
Recovery & $164 \pm 22$ & $29 \pm 15$ & $13 \pm 22$ \\
\hline
\end{tabular}

Each number is the mean for eight experiments. For the purposes of this analysis, the two experiments in subject 1 were not pooled. In an individual experiment four observations were made during baseline, two during glucagon and glucagon plus insulin, and one during recovery periods

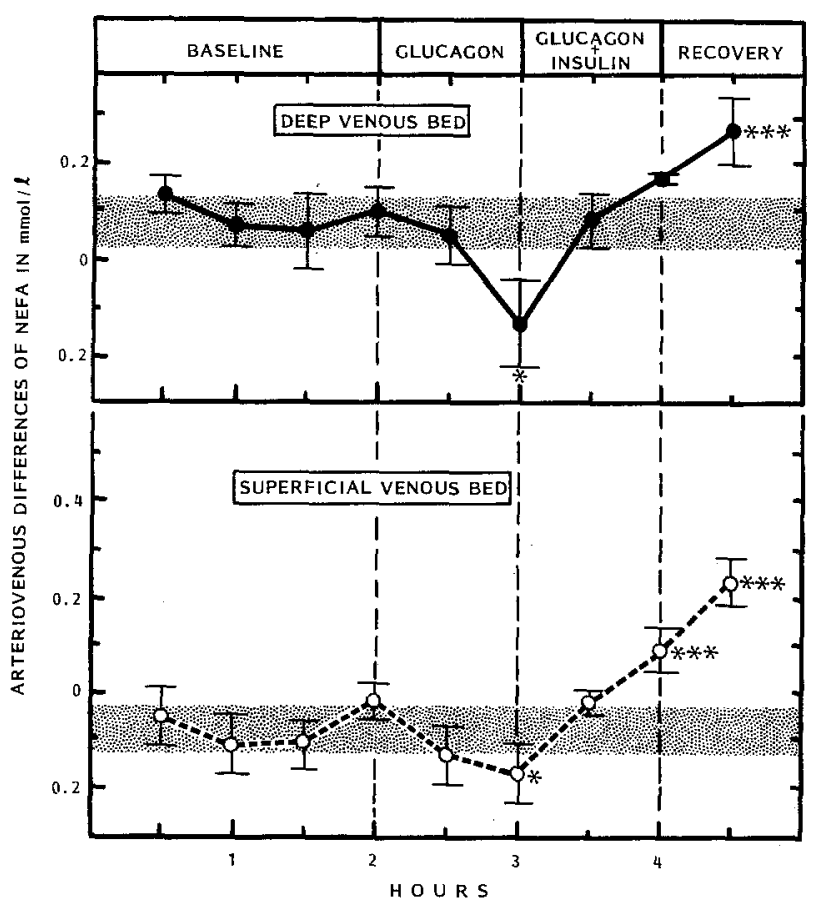

Fig. 1. Mean arteriovenous differences of NEFA (mmol/1, \pm SEM) in the human forearm during glucagon infusion. The shaded area indicates the baseline arteriovenous differences \pm SEM. Data from seven individuals are shown. Significant differences relative to baseline are indicated by an asterisk(s): *, p $<0.05$, **, p $<$ 0.025 , and $* * *, \mathrm{p}<0.01$

Deep and superficial beds are compared with respect to arteriovenous differences in Table 1 . These differences indicated relatively more output from the superficial bed of NEFA, glycerol, and pyruvate.
Hormone Levels (Table 3)

Mean arterial levels of insulin were stable (7.3 \pm $1.8 \mathrm{mU} / \mathrm{l}$ ) until insulin perfusion was begun. There was then a small rise in mean systemic insulin concentrations $(13.1 \pm 3.7 \mathrm{mU} / \mathrm{l})$. Perfusion of insulin into the brachial artery resulted in a mean increment in forearm plasma insulin concentrations of $104.5 \mathrm{mU} / 1$ (mean of deep and superficial venous increments). Increases in insulin levels ranged from 40 to $200 \mathrm{mU} / 1$. Concentrations returned to baseline levels during the recovery period.

Arterial levels of glucagon in the post-absorptive state were $117 \pm 22 \mathrm{pg} / \mathrm{ml}$. Systemic levels rose during glucagon perfusion alone to a mean of $167 \pm$ $23 \mathrm{pg} / \mathrm{ml}$ and continued to rise during perfusion of glucagon and insulin to a final level of $224 \pm 62 \mathrm{pg} /$ $\mathrm{ml}$. During recovery, systemic levels fell to a mean of $164 \pm 22 \mathrm{pg} / \mathrm{ml}$. The mean increment in forearm plasma glucagon levels during glucagon perfusion was $691 \mathrm{pg} / \mathrm{ml}$, and during perfusion of glucagon and insulin, $715 \mathrm{pg} / \mathrm{ml}$. During the recovery period significant arteriovenous differences of glucagon were no longer detectable. There was a large intersubject variation in venous plasma glucagon increments achieved, with a range between $200-1300 \mathrm{pg} / \mathrm{ml}$.

\section{Glucagon Effects upon Lipolysis}

Perfusion of glucagon stimulated lipolysis significantly in both the deep and superficial tissue compartments as indicated by increased release of NEFA (Fig. 1, Table 4). Mean deep arteriovenous differences of NEFA which were positive during the baseline period, became negative at $60 \mathrm{~min}$. The change in A-DV relative to baseline at $60 \mathrm{~min}$ of perfusion was $-0.226 \pm 0.101 \mathrm{mmol} / 1, \mathrm{p}<0.05$. The change in deep compartment $Q^{\circ}$ NEFA for the entire glucagon period was $-0.196 \pm 0.088 \mu \mathrm{mol}$ $\mathrm{min}^{-1} 100 \mathrm{ml}^{-1}$ of forearm tissue, $\mathrm{p}<0.025$ (Table 2) indicating either decreased uptake of NEFA or increased output. The within period relative arteriovenous differences of NEFA across the superficial compartment became negative in six of seven subjects at $30 \mathrm{~min}$ of perfusion and significantly negative at $60 \mathrm{~min}$ (Table 4). The net difference from baseline at $60 \mathrm{~min}$ was $-0.117 \pm 0.049 \mathrm{mmol} / \mathrm{ml}(\mathrm{p}$ $<0.05, \mathrm{n}=7$ ).

In the six subjects in whom glycerol was measured, changes in arteriovenous differences of glycerol paralleled those of NEFA, with significant effects seen at $60 \mathrm{~min}$ (net change of $-0.022 \pm$ $0.010, \mathrm{p}<0.05, \mathrm{n}=6$, Table 5). When flow was taken into account the change in glycerol output across deep tissues at $60 \mathrm{~min}$ was $-0.044 \pm$ 
Table 4. Net change in arteriovenous differences of NEFA ${ }^{a}$

\begin{tabular}{|c|c|c|c|c|c|c|}
\hline \multirow[b]{2}{*}{ Subject } & \multirow[b]{2}{*}{ Baseline } & \multicolumn{2}{|c|}{ Glucagon $^{\mathrm{b}}$} & \multicolumn{2}{|c|}{ Glucagon + insulin $^{\mathrm{b}}$} & \multirow{2}{*}{$\begin{array}{l}\text { Recovery } \\
150 \mathrm{~min}^{\mathrm{b}}\end{array}$} \\
\hline & & $30 \mathrm{~min}$ & $60 \min$ & $\overline{90} \min$ & $120 \mathrm{~min}$ & \\
\hline & & \multicolumn{5}{|c|}{ Deep venous } \\
\hline 1 & -0.125 & -0.113 & -0.267 & 0.194 & 0.348 & 0.297 \\
\hline 2 & 0.102 & 0.049 & -0.046 & 0.002 & 0.073 & 0.073 \\
\hline 3 & 0.039 & -0.087 & -0.040 & -0.011 & 0.136 & 0.071 \\
\hline 4 & 0.222 & -0.068 & -0.797 & -0.376 & -0.086 & 0.013 \\
\hline 5 & 0.170 & 0.030 & -0.130 & 0.223 & -0.035 & 0.322 \\
\hline 6 & 0.195 & -0.046 & -0.230 & -0.101 & -0.028 & 0.264 \\
\hline 7 & -0.029 & 0.027 & -0.074 & 0.068 & 0.191 & 0.153 \\
\hline Mean & - & -0.030 & -0.226 & 0.000 & 0.096 & 0.187 \\
\hline SED & - & 0.024 & 0.101 & 0.076 & 0.055 & 0.052 \\
\hline \multirow[t]{2}{*}{$\mathrm{p}$} & - & $N S^{c}$ & $<0.05^{\mathrm{c}}$ & $N^{d}$ & $N S^{d}$ & $<0.01^{\mathrm{d}}$ \\
\hline & & \multicolumn{5}{|c|}{ Superficial venous } \\
\hline 1 & -0.184 & -0.076 & -0.114 & 0.154 & 0.284 & 0.395 \\
\hline 2 & -0.084 & -0.060 & -0.058 & 0.106 & -0.023 & 0.042 \\
\hline 3 & 0.008 & -0.048 & 0.004 & -0.028 & 0.127 & 0.171 \\
\hline 4 & -0.317 & -0.043 & -0.043 & 0.303 & 0.303 & 0.466 \\
\hline 5 & -0.063 & -0.120 & -0.318 & 0.104 & 0.194 & 0.338 \\
\hline 6 & 0.124 & -0.084 & -0.281 & -0.247 & 0.063 & 0.278 \\
\hline 7 & -0.048 & 0.121 & -0.008 & 0.058 & 0.319 & 0.189 \\
\hline Mean & - & -0.044 & -0.117 & 0.064 & 0.181 & 0.268 \\
\hline SED & - & 0.029 & 0.049 & 0.064 & 0.050 & 0.055 \\
\hline $\mathrm{p}$ & - & $N S^{c}$ & $<0.05^{\mathrm{c}}$ & $N S^{\mathrm{d}}$ & $<0.001^{\mathrm{d}}$ & $<0.01^{\mathrm{d}}$ \\
\hline
\end{tabular}

a Results given in mmol/1

b The column headings indicate minutes after beginning glucagon perfusion

c Probability that a value is more negative than baseline

${ }^{d}$ Probability that a mean value is more positive than baseline

$0.019 \mu \mathrm{mol} \mathrm{min} \mathrm{m}^{-1} 100 \mathrm{ml}^{-1}$ of forearm tissue, $(\mathrm{p}<$ $0.050, n=6)$. Changes in superficial bed arteriovenous differences were not significant.

\section{Glucagon Effects on Glucose Uptake and Potassium Movement}

There was a decrease in glucose arteriovenous differences across the deep and superficial beds with glucagon (Fig. 2). Decreased deep differences were found in all subjects, whereas decreases in the superficial differences were seen in five of seven subjects. Net changes in deep and superficial arteriovenous differences of glucose were maximal $60 \mathrm{~min}$ after glucagon perfusions were begun, $-0.24 \pm 0.09$ and $-0.10 \pm 0.05 \mathrm{mmol} / \mathrm{l}, \quad(\mathrm{p}<0.025$ and $<0.05$ respectively). The overall change in $\mathrm{Q}$ DV glucose during glucagon was $-0.25 \pm 0.13 \mu \mathrm{mol} \mathrm{min}^{-1}$ $100 \mathrm{ml}^{-1}$ of forearm tissue $(\mathrm{p}<0.05$, Table 2$)$.

In six of seven subjects mean (A-DV) potassium decreased during glucagon by $-0.11 \pm 0.05 \mathrm{mmol} / 1$ ( $\mathrm{p}<0.05, \mathrm{n}=6$, Fig. 3 and Table 5 ) and $\mathrm{Q}$ DV by $-0.29 \pm 0.14 \mu \mathrm{mol} \mathrm{min}{ }^{-1} 100 \mathrm{ml}^{-1}$ of forearm tissue $(\mathrm{p}<0.05, \mathrm{n}=6$, Table 3$)$. In subject 6 , arteriovenous differences increased relative to baseline, while in the others, decreased differences were observed for the $30 \mathrm{~min}$ period and for four of seven at the $60 \mathrm{~min}$ period (Table 5). There were no significant effects upon potassium movement in the superficial compartment.

\section{Ketone Body Utilisation, Pyruvate and Lactate} (Table 2)

Glucagon caused no significant alterations in utilisation or output of these substrates.

\section{The Simultaneous Perfusion of Insulin and Glucagon} (Figs. 1, 2 and 3; Tables 2, 4, and 5)

Simultaneous perfusion of insulin with glucagon resulted in a reversal of the effects of glucagon. Inhibition of glucagon mediated lipolysis across the superficial tissues (Fig. 1 and Table 4) was indicated by a net increase in (A-SV) NEFA relative to the glucagon and baseline periods. Similar alterations were observed across the deep tissues of the forearm (Fig. 2, Tables 2 and 4). (A-DV) NEFA which were 


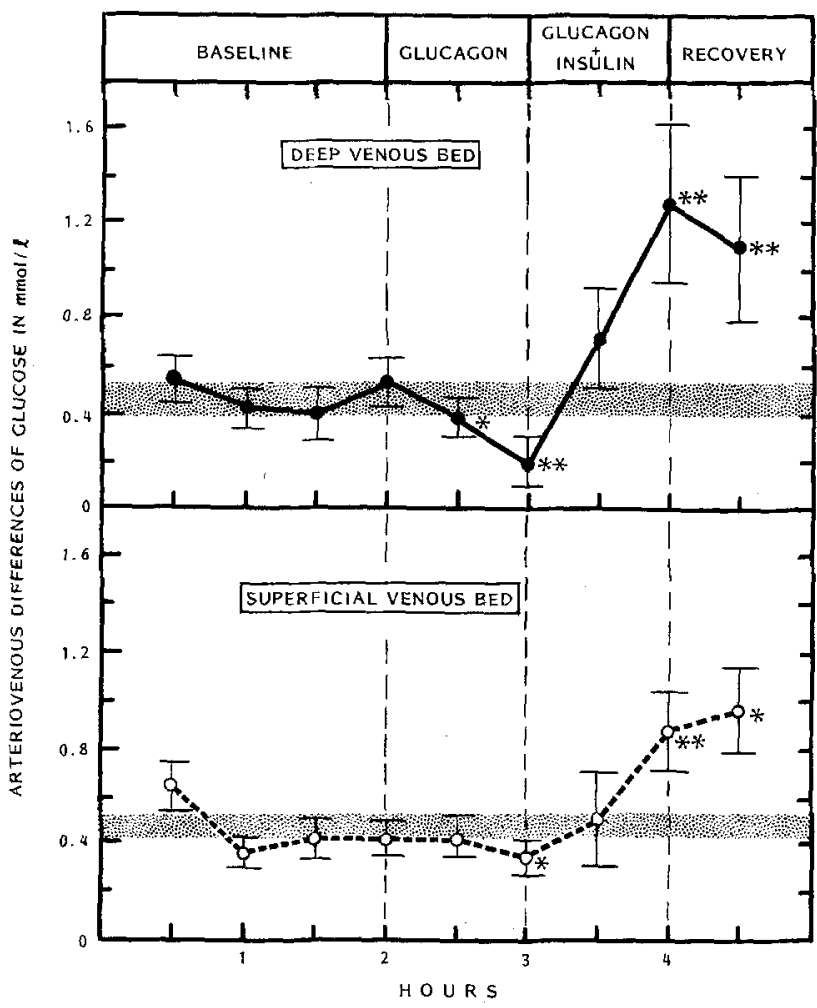

Fig. 2. Mean arteriovenous differences of glucose. Details as in Figure 1

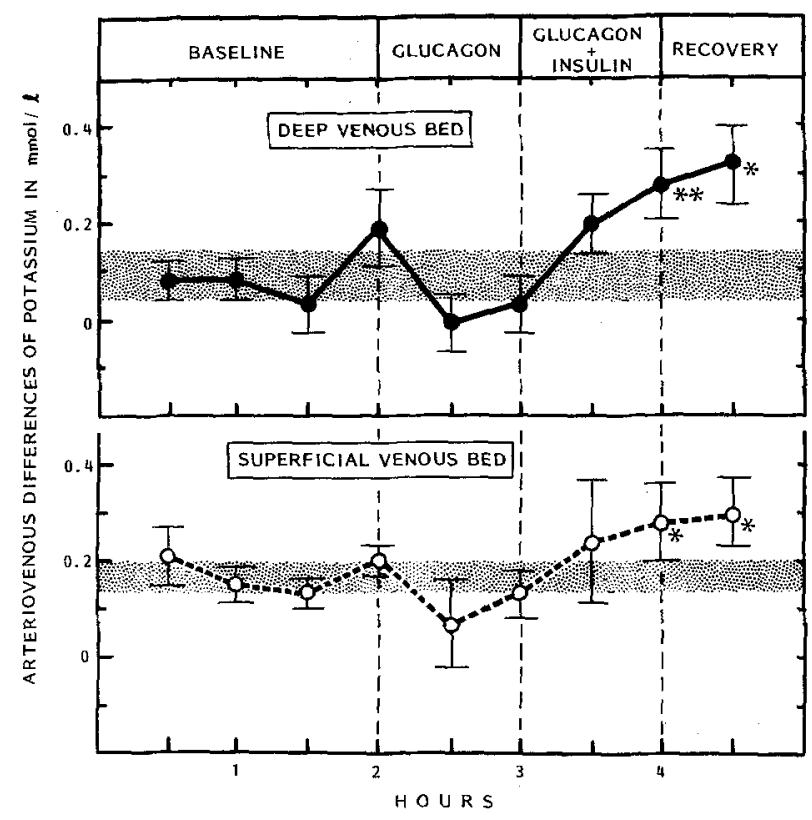

Fig. 3. Mean arteriovenous differences of potassium. Details as in Figure 1

Table 5. Net change in deep arteriovenous differences of glycerol and potassium relative to baseline ${ }^{\mathrm{a}}$

\begin{tabular}{|c|c|c|c|c|c|c|}
\hline \multirow[b]{2}{*}{ Subject } & \multirow[b]{2}{*}{ Baseline } & \multicolumn{2}{|c|}{ Glucagon $^{b}$} & \multicolumn{2}{|c|}{ Glucagon + insulin $^{b}$} & \multirow{2}{*}{$\begin{array}{l}\text { Recovery } \\
150 \text { min }\end{array}$} \\
\hline & & $30 \mathrm{~min}$ & $60 \mathrm{~min}$ & $90 \mathrm{~min}$ & $120 \mathrm{~min}$ & \\
\hline \multicolumn{7}{|l|}{ Glycerol } \\
\hline 1 & -0.037 & -0.039 & -0.060 & 0.001 & 0.022 & 0.026 \\
\hline 2 & 0.013 & -0.003 & -0.023 & 0.048 & 0.168 & -0.003 \\
\hline 3 & 0.013 & -0.033 & -0.033 & -0.033 & -0.023 & 0.047 \\
\hline 4 & 0.005 & -0.035 & -0.025 & 0.015 & 0.025 & 0.055 \\
\hline 5 & 0.013 & 0.037 & 0.007 & 0.017 & -0.003 & 0.027 \\
\hline 6 & - & - & - & - & - & - \\
\hline 7 & -0.010 & 0 & 0 & 0.020 & 0 & 0 \\
\hline Mean & - & -0.014 & -0.022 & 0.011 & 0.032 & 0.025 \\
\hline SED & - & 0.013 & 0.010 & 0.011 & 0.028 & 0.010 \\
\hline $\mathrm{p}$ & - & $\mathrm{NS}^{\mathrm{c}}$ & $<0.05^{\mathrm{c}}$ & $\mathrm{NS}^{d}$ & $N S^{d}$ & $<0.05^{\mathrm{d}}$ \\
\hline \multicolumn{7}{|l|}{ Potassium } \\
\hline 1 & 0.15 & -0.06 & -0.11 & 0.20 & 0.25 & 0.31 \\
\hline 2 & 0.03 & -0.03 & -0.07 & 0.18 & 0.48 & 0.08 \\
\hline 3 & 0.10 & -0.14 & -0.30 & -0.18 & 0.07 & 0 \\
\hline 4 & 0.24 & -0.21 & -0.22 & -0.03 & 0.28 & 0.06 \\
\hline 5 & -0.14 & -0.11 & 0.06 & 0.38 & 0.61 & 0.065 \\
\hline 6 & 0.07 & 0.14 & 0.24 & 0.30 & 0.46 & 0.55 \\
\hline 7 & 0.15 & -0.28 & -0.14 & -0.06 & -0.14 & 0 \\
\hline Mean & - & -0.10 & -0.06 & 0.11 & 0.29 & 0.24 \\
\hline SED & - & 0.05 & 0.07 & 0.08 & 0.11 & 0.10 \\
\hline $\mathrm{p}$ & - & $N S^{c}$ & $\mathrm{NS}^{\mathrm{c}}$ & $N S^{d}$ & $<0.025^{\mathrm{d}}$ & $<0.05^{\mathrm{d}}$ \\
\hline
\end{tabular}

\footnotetext{
a Results given in $\mathrm{mmol} / \mathrm{l}$

$b$ The column headings indicate minutes after beginning glucagon perfusion

c Probability that a value is more negative than baseline

"Probability that a value is more positive than baseline
} 
significantly ncgative relative to baseline during glucagon became positive with respect to the glucagon period $(0.172 \pm 0.043 \mu \mathrm{mol} / \mathrm{ml}, \mathrm{p}<0.01)$ and were no longer distinguishable from baseline values.

The effects of insulin on glucose and potassium (Figs. 2 and 3, Tables 2 and 5) were opposite to those of glucagon. (A-SV) and (A-DV) glucose were increased significantly during perfusion relative to baseline and glucagon periods (also observed for $\mathrm{Q}$ DV glucose). Changes in A-SV and A-DV glucose relative to the glucagon periods were $0.41 \pm$ 0.14 and $0.73 \pm 0.20 \mu \mathrm{mol} / \mathrm{ml}$ for both $(p<0.025$. Mean (A-SV) potassium levels were increased over baseline by insulin at $60 \mathrm{~min}$ of perfusion by $0.15 \pm$ $0.06,(p<0.05)$. (A-DV) and $\mathrm{Q}^{\circ} \mathrm{DV}$ potassium were significantly increased over both bascline and glucagon perfusion periods by insulin.

\section{Recovery Period (Figs. 1, 2 and 3; Tables 2, 4 and 5)}

During recovery significant insulin effects upon glucose, potassium, and NEFA were discernible in the deep and superficial tissues, relative to baseline.

\section{Discussion}

The objectives of these experiments were to determine whether pathophysiological concentrations of glucagon at the top end of the range found in ketoacidosis would stimulate lipolysis, affect substrate utilisation and/or interfere with insulin action. In vitro and in vivo human studies have been contradictory $[10,14,22,23,24]$ concerning the lipolytic and contra-insulin effects of glucagon. Enhanced insulin secretion in individuals during the infusion of glucagon probably accounts for much of the confusion concerning in vivo human studies $[25,26]$, since the lipolytic response to glucagon could be blocked with insulin concentrations as low as $25 \mathrm{mU} / 1$ [26].

Blockade of the expected increase in glucagon during acute insulin withdrawal in insulin dependent diabetics results in a substantial reduction of NEFA concentrations and ketone bodies $[13,27]$. However, somatostatin therapy in cstablished ketoacidosis does not reverse the metabolic disturbances implying that glucagon worsens but does not initiate the metabolic disturbance [28]. Glucagon concentrations frequently exceed $1000 \mathrm{pg} / \mathrm{ml}$ in ketoacidosis [6]. Further, Raskin and Unger have shown that when glucagon was suppressed in insulin dependent diabetics by a $48 \mathrm{~h}$ infusion of somatostatin, metabolic abnormalities were normalized [29].

In the studies described in this paper, increases in glucagon levels of approximately $700 \mathrm{pg} / \mathrm{ml}$ were associated with a significant relcase of NEFA across both the deep and superficial venous compartments of the forearm. Mean glycerol A-DV also became more negative than baseline and output across deep tissue increased significantly. However, significant glycerol output from superficial tissues was not observed. This was in keeping with the small magnitude of changes observed in lipolysis, the lesser blood flow and tissuc mass in the superficial venous compartment and the relatively large capacity for lipolytic activity of the muscle containing deep venous compartment $[30,31]$. Despite significant increases in systemic glucagon levels, arterial insulin, NEFA, and glycerol levels did not change. This demonstrated that systemic lipolysis was not induced by a doubling of glucagon in the presence of normal post-absorptive concentrations of insulin and is consistent with results reported by others [32].

The results presented in this paper apparently conflict with the findings of Pozefsky et al. [33], who were unable to demonstrate lipolytic effects of glucagon using a similar technique. These workers studied both post-absorptive and $50 \mathrm{~h}$ fasted individuals. In the latter case, endogenous glucagon levels, systemic lipolysis, as well as intracellular levels of NEFA are maximal [22]. Despitc the significant decrease in insulin levels associated with prolonged fasting, the peak glucagon effects may already have been present making additional effects difficult to demonstrate. In the former studies, NEFA data were not shown. Because lipolytic effects were small in magnitude, measurements of NEFA may be required to detect these effects, since NEFA: glycerol ratios exceed $3: 1$ during lipolysis in man [31].

Glucagon-enhanced lipolysis was associated with decreased glucose uptake across both venous beds. This finding was reminiscent of the competitive process between fatty acid and glucose utilisation first described by Randle ct al. [34]. Evidence in the literature suggested that the intracellular rather than extracellular concentrations of NEFA were important in the regulation of glucose uptake [35]. Lindsey and Madison have previously shown that glucagon administration in the dog led to a decrease in peripheral glucose disposal by up to $40 \%$ [36]. In the experiments we have presented, acute elevations in glucagon concentrations were associated with a greater than $30 \%$ decrease in net glucose arteriovenous differences across both the superficial and deep venous beds in association with enhanced lipolysis. Unfortunatcly, we could not perform respiratory quotient mcasurements during these studies and cannot comment on the utilisation of tissue glycogen in the presence of glucagon increments. Glucagon may have exerted its effects upon glucose uptake by 
increasing intracellular concentrations of NEFA and thereby NEFA utilisation. This effect of glucagon may contribute to glucose sparing during periods of active lipolysis.

The effects of glucagon upon potassium movement tended to parallel those on glucose. A hyperkalaemic effect of glucagon was first observed by Wolffson and Ellis [37]. Galansino et al. reported that glucagon perfusion across liver resulted in increased potassium output, and more recently, evidence has accumulated that glucagon contributes to renal potassium loss $[38,39]$. Thus, glucagon may contribute to potassium depletion in insulin deficiency by direct tissue loss and enhancement of renal excretion.

Insulin concentrations similar to those observed in the post-prandial state readily reversed the lipolytic effects of glucagon, despite the continued presence of increased glucagon concentrations. In addition to blockade of lipolysis, insulin also promoted a rapid and complete reversal of glucagon effects upon glucose and potassium uptake. While a significant portion of the effects of insulin on glucose uptake are due to direct enhancement of glucose uptake by tissues, insulin may also act indirectly by blocking glucagon stimulated lipolysis. The anti-glucagon effects of insulin which were demonstrated during the perfusion of both hormones make it likely that glucagon's effects upon peripheral tissues are of importance only during states of relative or absolute insulin deficiency.

Acknowledgements. We wish to thank Ms. Randi Boxaspen and Ms. Mary Trerice (laboratory of Dr. George Blackburn) for their technical assistance, Ms. Marta Smith for preparation and review of this manuscript, and Drs. John Galloway and Mary Root of Eli Lilly Laboratories for their gift of insulin, glucagon and immunoassay reagents. This work was supported in part by NIH Grants AM 21353, GCRC Division of Research Resources Grant RR533, and a Research and Development Award of the American Diabetes Association (S. E. Fineberg, M D., recipient.)

\section{References}

1. Sherwin RS, Baśtl C, Finkelstein FO, Fisher M, Black H, Hendler R, Felig P (1976) Influence of uremia and hemodialysis on the turnover and metabolic effects of glucagon. J Clin Invest 57: 722-731

2. Sherwin RS, Joshi P, Hendler R, Felig P, Conn HO (1974) Hyperglucagonemia in Laennec's cirrhosis. N Engl J Med 290: 239-242

3. Meguid MM, Brennan MF, Aoki TT, Muller WA, Ball MR, Moore FD (1974) Hormones - substrate interrelationships following trauma. Arch Surg 109: 776-783

4. Rocha DM, Santeusanio F, Faloona GR, Unger RH (1973) Abnormal pancreatic alpha cell function in bacterial infection. N Engl J Med 228: 700-703

5. Johnston DI, Bloom SR, O'Brian D (1975) Pancreatic glucagon in diabetic ketoacidosis. Arch Dis Child 50: 329
6. Muller WA, Faloona GR, Unger RH (1973) Hyperglucagonemia in diabetic ketoacidosis Am J Med 54: 52-57

7. Kuku SF, Jaspan JB, Emmanouel DS, Zeidler A, Katz AI, Rubenstein AH (1976) Heterogeneity of plasma glucagon: Circulating components in normal subjects and patients with chronic renal failure. J Clin Invest 58: 742-750

8. Williams RH (1974) In: Williams RH (ed) Williams' textbook of endocrinology, 5th ed. Saunders, Philadelphia p 547-550

9. Lefebvre PJ, Luyckx A (1968) Lipolytic action of glucagon in vitro and in vivo. Exerpta Medica Monograph: Pathophysiology of adipose tissue, p 257-267

10. Lefebvre PJ (1972) Glucagon and lipid metabolism. In: Lefebvre PJ, Unger RH (eds) Glucagon: Molecular physiology, clinical and therapeutic implications. Pergamon Press, Oxford New York, p 109-121

11. Lefebvre PJ (1975) Glucagon and adipose tissue. Biochem Pharmacol 24: 1261-1266

12. Sarcione EJ, Back N, Sokal JE, Mehlman B, Knoblock E (1963) Elevation of plasma epinephrine levels produced by glucagon in vivo. Endocrinology 72: 523-526

13. Gerich JE, Lorenzi M, Bier D, Schneider V, Tsalikian E, Karam JH, Forsham PH (1975) Prevention of human diabetic ketoacidosis by somatostatin. Evidence for an essential role of glucagon. N Engl J Med 292: 985-990

14. Lefebvre, PJ, Luyckx AS (1979) Glucagon and diabetes: A reappraisal. Diabetologia 15: 347-354

15. Fineberg SE, Merimee TJ (1973) Effects of comparative perfusions of equimolar, single component insulin and proinsulin in the human forearm. Diabetes 22: 676-685

16. Andres R, Zierler KL, Anderson H, Stainsby W, Cader G, Ghrayyib A, Lilienthal J (1954) Measurements of blood flow and volume in the forearm of man with notes on the theory of indicator dilution and on the production of turbulence, hemolysis, and vasodilitation by intravascular injection. $\mathrm{J}$ Clin Invest 33: 482-504

17. Wahren J (1966) Quantitative aspects of blood flow and oxygen uptake in the human forearm during rhythmic exercise. Acta Physiol Scand [Suppl] 67: 269

18. Bergmeyer J (ed) (1974) Methods of enzymatic analysis. Academic Press, New York

19. Novak M (1965) Colorimetric ultramicro method for the determination of free fatty acids. J Lipid Res 6: 431-433

20. Baltzan MA, Andres R, Cader G, Zierler KL (1962) Heterogeneity of forearm metabolism with special reference to free fatty acids. J Clin Invest 41: 116-125

21. Dixon W, Massey F Jr (1969) Introduction to statistical analysis. McGraw-Hill Book Co, New York

22. Marliss EB, Aoki TT, Unger RH, Soeldner JS, Cahill GF (1970) Glucagon levels and metabolic effects in fasting man. J Clin Invest 49: 2256-2262

23. Schade DS, Eaton RP (1975) Modulation of fatty acid metabolism by glucagon in man. Diabetes 24: 502-515

24. Liljenquist JE, Bomboy JD, Lewis SB, Sinclair-Smith BL, Felts PW, Lacy WW, Crofford OB, Liddle G (1974) Effects of glucagon on lipolysis and ketogenesis in normal and diabetic men. J Clin Invest 53: 190-197

25. Schade DS, Eaton RP (1975) The contribution of endogenous insulin secretion to ketogenic responses to glucagon in man. Diabetologia 11: 555-562

26. Froesch RE, Burgi H, Bally P, Labhart A (1965) Insulin inhibition of spontaneous adipose tissue lipolysis and effects of fructose and glucose metabolism. Mol Pharmacol 1: 280-296

27. Gerich JE, Lorenzi M, Bier DM, Tsalikian E, Schneider V, Karam JH, Forsham PH (1976) Effects of physiologic levels of glucagon and human growth hormone on human carbohydrate and lipid metabolism. J Clin Invest 57: 875-884

28. Ludabaek K, Christensen SE, Hansen AP, Iversen J, Orskov 
H, Sever-Hansen K, Alberti KGMM, Whitefoot R (1976) Failure of somatostatin to correct manifest diabetic ketoacidosis. Lancet II: 215-218

29. Raskin P, Unger RII (1978) Hyperglucagonemia and its suppression: Importance in the metabolic control of diabetes. $\mathrm{N}$ Engl J Med 299: 1366-1367

30. Dagenais GR, Tancredi RG, Zierler KI. (1976) FFA oxidation by forcarm muscle at rest, and evidence for an intramuscular lipid pool in human forcarm. J Clin Invest 58: $421-431$

31. Heaf DJ, Kaijser L, Eklund B, Carson I.A (1977) Differences in heparin-rcleased lipolytic activity in the superficial and deep veins of the human forearm. Eur J Clin Invest 7: 195-199

32. Aoki TT, Muller WA, Brennan, MF, Cahill GF (1974) Effect of glucagon on amino acid and nitrogen metabolism in fasting man. Metabolism 23: 805-814

33. Pozefsky T, Tancredi R, Moxley R, Dupre J, Tobin J (1976) Metabolism of forearm tissues in man. Studies with glucagon. Diabctes 25: 128-136

34. Randle PJ, Garland PB, Hales CN, Newsholme EA (1963) The glucose-fatty acid cycle: Its roles in insulin sensitivity and metabolic disturbances of diabetes mellitus. Lancet I: 785-789

35. Schonfeld G, Kipnis D (1968) Effect of free fatty acids on carbohydrate and fatty acid metabolism in rat diaphragm. Am J Physiol 215: 513-522
36. Lindsey AL, Madison LL (1972) Is glucagon a gluconcogenic hormone in vivo? Diabctes 21 [Suppl 1]: 331

37. Wolfson SK, Ellis S (1956) Effects of glucagon on plasma potassium. Proc Soc Exp Biol Med 91: 226-228

38. Galansino G, D'Amico G, Kanameishi D, Berlinger F, Foa $P$ (1960) Hyperglycemic substances originating in the pancreatoduodenal area. Am J Physiol 198: 1059-1062

39. Pullman T, Lavender A, Aho I (1967) Direct effects of glucagon on renal hemodynamics and excretion of inorganic ions. Metabolism 16: 358-373

Received: April 8, 1980, and in revised form: December 31, 1980

S. Edwin Fineberg, M. D.

Department of Medicine

Division of Endocrinology

Indiana University School of Medicine

1100 West Michigan Street

Indianapolis, IN 46223

LSA 